\title{
ANALISIS PENGARUH BUDAYA ORGANISASI, KOMPETENSI DAN MOTIVASI TERHADAP KINERJA KARYAWAN (STUDI PADA PDAM TIRTA BINANGUN KULONPROGO)
}

\author{
Vita Vitria \\ vitriaavitaa@gmail.com \\ Universitas Ahmad Dahlan \\ Ani Muttaqiyathun \\ animtq@gmail.com \\ Universitas Ahmad Dahlan
}

\begin{abstract}
ABSTRAK
This study aims to determine: (1) the influence of organizational culture, competence and motivation for the performance of PDAM Tirta Binangun's employees Kulonprogo Regency, (2) the influence of organizational culture on performance PDAM Tirta Binangun employees, Kulonprogo Regency, (3) influence competence in the performance of PDAM Tirta Binangun Regency employees Kulonrogo, (4) the influence of motivation on the performance of employees of PDAM Tirta Binangun Kulonprogo Regency. The sample in this study were employees of PDAM Tirta Binangun Kulonrogo Regency with a total of 60 employees with engineering leadership agency / institutional sample. Data collection using questionnaire while data analysis was performed using regression analysis linear multiple. Testing the validity in this study uses correlation product moment. Hypothesis testing using the $\mathrm{F}$ test and t test. At a significance level of 5\%, the results of the study show that: (1) culture organization, competence and motivation simultaneously have influence significant effect on the performance of employees of PDAM Tirta Binangun Kulonprogo Regency is indicated by a sign count value of $0,000<0.05$. (2) organizational culture has a significant effect on the performance of employees of PDAM Tirta Binangun Kulonprogo Regency is indicated by the calculated sign value of $0.012<0.05$. (3) competence has a significant effect on the performance of PDAM employees Tirta Binangun Kulonprogo Regency is indicated by the calculated sign value $0.022<0.05$. (4) motivation has a significant effect on employee performance PDAM Tirta Binangun Kulonprogo Regency is indicated by a sign value count $0.016<0.05$.
\end{abstract}

Keywords: Organizational Culture, Competence, Motivation and Employee Performance.

\begin{tabular}{l}
\hline \multicolumn{4}{c}{ PENDAHULUAN } \\
\hline \multicolumn{2}{c}{ Di era globalisasi ini sebuah } \\
perusahaan pasti sangat membutuhkan \\
manajemen sumber daya manusia karena \\
sebagai rangkaian aktivitas organisasi \\
yang diarahkan untuk menarik, \\
mengembangkan dan mempertahankan \\
tenaga kerja yang efektif dan efisien. \\
Dengan adanya manajemen sumber daya \\
manusia yang baik akan membuat \\
perusahaan dapat bekerja sama dengan
\end{tabular}

karyawan sehingga dapat mewujudkan tujuan perusahaan dan mampu memberikan kinerja yang maksimal kepada perusahaan yang dapat membawa pengaruh pada nilai perusahaan baik secara jangka pendek maupun jangka panjang.

Sebuah perusahaan pasti berkeinginan membangun kualitas kinerja yang baik, kinerja yang baik tidak akan tercapai tanpa adanya dukungan dari kinerja para karyawan. Oleh karena itu, perusahaan harus merencanakan 
pengembangan kualitas para karyawan artinya organisasi tersebut berusaha membangun dan menciptakan suatu kekuatan yang berkualitas dalam suatu organisasi pada perusahaan. Apalagi diperusahaan air minum daerah sangat memerlukan manajemen sumber daya manusia yang baik untuk mengoptimalkan layanan kepada masyarakat yang sangat membutuhkan air bersih untuk keperluan sehari-hari.

Salah satu faktor yang dapat mencapai tujuan perusahaan adalah kinerja karyawan. Menurut Sinambela (2012) menyatakan bahwa kinerja adalah pelaksanaan suatu pekerjaan dan penyempurnaan pekerjaan tersebut sesuai dengan tanggung jawabnya, sehingga dapat mencapai hasil sesuai dengan yang diharapkan. Semua perusahaan pasti mengharapkan karyawan yang memiliki kualitas kinerja yang baik dan bertanggung jawab terhadap pekerjaannya, tetapi tidak semudah itu mendapatkan karyawan yang sesuai dengan target karena harus dilakukan dengan usaha kerja keras dari perusahaan itu sendiri untuk memperoleh karyawan yang baik. Perusahaan juga pasti menginginkan karyawan yang mempunyai prestasi dan usaha yang maksimal karena dengan memiliki karyawan yang berkualitas menjadikan itu sebagai dorongan untuk perusahaan agar dapat terus mengembangkan usaha perusahaan.

Dalam sebuah perusahaan juga pasti memiliki budaya organisasi yang berbedabeda. Menurut Robbins (2017) menyatakan budaya organisasi adalah suatu sistem berbagi arti yang dilakukan oleh para anggota yang membedakan suatu organisasi dari organisasi lainnya. Sebuah perusahaan pasti akan berusaha memperlihatkan bentuk budaya yang menjadi gaya dan kekuatan yang membedakan perusahaan satu sama lain. Budaya organisasi memiliki pengaruh yang kuat dalam membentuk standar etika yang tinggi dari para anggota karyawan. Jika suatu budaya kuat dan mendukung standar etika yang tinggi, maka akan memiliki pengaruh yang sangat baik dan positif terhadap perilaku pekerja untuk mendorong terjadinya peningkatan keefektifan dan kompetensi pada perusahaan tersebut. Hal ini ditunjukkan masih ada karyawan yang belum sepenuhnya mentaati ketentuan jam kerja, kurang disiplin dan masih terlihat pegawai ngobrol bersantai. Keadaan ini sudah tidak dapat dibiarkan, karena apabila dibiarkan berlarut-larut dapat mengarah kepada tindakan karyawan tidak setia, karyawan mengabaikan seperti mangkir atau datang terlambat, mengurangi kualitas dan kuantitas kerja serta tingkat kesalahan kerja meningkat.

Usaha untuk meningkatkan kinerja karyawan yaitu dari kompetensinya. Menurut Wibowo (2014) menyatakan bahwa kompetensi adalah suatu kemampuan untuk melaksanakan atau melakukan sesuatu pekerjaan atau tugas yang dilandasi atas ketrampilan dan pengetahuan serta didukung oleh sikap kerja yang dituntut oleh pekerjaan tersebut. Kompetensi sebagai salah satu faktor yang ada pada masing-masing karyawan. Dengan adanya kompetensi perusahaan semakin mudah menetapkan karyawannya untuk bekerja dibidang yang sesuai dengan kemampuannya sehingga dapat meningkatkan kinerja. Sudah banyak upaya yang dilakukan untuk meningkatkan kinerja karyawan secara keseluruhan, dengan menggunakan sumberdaya, teknologi, sarana kerja, serta peningkatan keterampilan dan kemampuan pegawai melalui berbagai kursus atau pelatihan. Namun ternyata kinerja karyawan PDAM belum maksimal. Hal ini dapat dilihat dari hasil kinerja yang masih rendah dan proses kerja yang belum optimal dan harus didasari dengan motivasi yang diberikan perusahaan untuk bisa tetap mengembangkan kemampuan yang dimiliki setiap karyawan.

$$
\text { Menurut Robbins }
$$
menyatakan bahwa motivasi adalah proses yang menjelaskan mengenai kekuatan, 
arah dan ketekunan seseorang dalam upaya untuk mencapai tujuan. Dengan adanya motivasi karyawan lebih bisa mengapresiasikan dirinya terhadap lingkungan kerjanya setiap kegiatan yang dilakukan oleh karyawan didorong oleh suatu kemauan dalam diri orang tersebut. Bila seseorang karyawan termotivasi, ia akan berusaha berbuat sekuat tenaga untuk mewujudkan apa yang diinginkannya. Akan tetapi masih rendahnya kinerja dapat dilihat masih terjadi keterlambatan dalam pengurusan atau penyelesaian suatu berkas dan kurang cepatnya pelayanan yang diberikan karyawan. Hal ini masih merupakan kurangnya disiplin kerja sehingga para karyawan cenderung mengalami penurunan pada kinerjanya.

Penelitian ini mengambil obyek pada PDAM Tirta Binangun kabupaten Kulonprogo yang berlokasi di Jalan Khudori, Wates, Kulonprogo, Yogyakarta. Merupakan perusahaan yang bergerak dalam distribusi air bersih bagi masyarakat umum dan memiliki produk air kemasan. Kegiatan yang dilakukan PDAM Tirta Binangun yaitu memberikan pelayanan umum atau jasa dibidang penyediaan air minum, menyelenggarakan kemanfaatan umum penggunaan air bersih, memupuk pendapatan murni daerah dan pelaksanaan sesuai dengan tugas pokok dan berdasarkan Peraturan PerundangUndangan yang berlaku. Dalam wawancara langsung dengan Rian Hermawan bagian staf transmisi dan distribusi teknik PDAM Tirta Binangun Kulonprogo, terdapat masalah yang dihadapi oleh perusahaan, seperti masih banyak karyawan yang belum menaati ketentuan jam kerja, belum maksimal dalam menjalankan tugas dan menurunnya kinerja karyawan

Tujuan dari penelitian ini yaitu: 1) untuk mengetahui apakah budaya organisasi, kompetensi dan motivasi secara simultan berpengaruh signifikan terhadap kinerja karyawan pada perusahaan daerah air minum Tirta Binangun Kulonprogo, 2) untuk mengetahui apakah budaya organisasi berpengaruh signifikan terhadap kinerja karyawan pada perusahaan daerah air minum Tirta Binangun Kulonprogo, 3) untuk mengetahui apakah kompetensi berpengaruh signifikan terhadap kinerja karyawan pada perusahaan daerah air minum Tirta Binangun Kulonprogo dan 4) untuk mengetahui apakah motivasi berpengaruh signifikan terhadap kinerja karyawan pada perusahaan daerah air minum Tirta Binangun Kulonprogo.

\section{REVIEW LITERATUR DAN HIPOTESIS}

\section{Landasan Teori}

1. Budaya Organisasi

Menurut Kreitner

menyatakan budaya organisasi adalah satu wujud anggapan yang dimiliki, diterima secara implisit oleh kelompok dan menentukan bagaimana kelompok tersebut rasakan, pikirkan dan bereaksi terhadap lingkungannya yang beraneka ragam. Budaya organisasi diberikan kepada karyawan melalui proses sosialisasi untuk bisa mempengaruhi perilaku karyawan bagaimana cara atau setiap karyawan menerapkan budaya organisasi yang sudah ada pada perusahaan ini apakah dapat menyesuaikan diri untuk bisa memahami budaya pada perusahaan untuk menunjukan bahwa dirinya mampu mengaplikasikan budaya organisasi terhadap diri sendiri.

2. Kompetensi

Menurut Wibowo (2014) menyatakan bahwa kompetensi merupakan karakteristik yang mendasar pada setiap individu yang dihubungkan dengan kriteria yang direferensikan terhadap kinerja yang unggul atau efektif dalam sebuah pekerjaan atau situasi. Kemampuan yang dimiliki setiap individu untuk mengatur kemampuan yang ada pada dirinya bagaimana cara mengelola 
untuk mendapatkan atau mengerjakan kinerja dengan baik sesuai kemampuan yang ada pada dirinya, jika seorang individu percaya memiliki kemampuan yang baik maka dapat mempengaruhi kinerja dan meningkatkan kemampuan yang dimilikinya pasti akan menunjukan rasa optimis bahwa dirinya bisa menunjukan kinerja yang bagus.

\section{Motivasi}

Menurut Kreitner (2005) menyatakan bahwa motivasi adalah proses-proses psikologis yang meningkatkan dan mengarahkan perilaku untuk mencapai tujuan. Proses pengembangan diri yang diberikan perusahaan untuk memberikan semangat terhadap individu ataupun kelompok yang ada pada perusahaan itu untuk memberikan arahan yang baik dalam mengerjakan tugas yang diberikan untuk menghasilkan kinerja yang bagus dan sesuai dengan harapan yang diinginkan oleh perusahaan.

4. Kinerja Karyawan

$$
\text { Menurut Fahmi (2016) }
$$

menyatakan bahwa kinerja adalah hasil yang diperoleh oleh suatu organisasi baik organisasi tersebut bersifat profit oriented dan non profit oriented yang dihasilkan selama satu periode tertentu. Suatu hasil usaha yang dilakukan oleh individu ataupun kelompok dalam satu waktu tertentu untuk menyelesaikan tugas yang sudah diberikan oleh atasan dengan berusaha menunjukan hasil yang baik meskipun hasil yang dikerjakan kadang menunjukan hasil yang baik ataupun hasil yang kurang baik semua butuh proses untuk mengerjakannya dengan tujuan untuk menghasilkan kinerja yang sesuai.

\section{Penelitian Terdahulu}

Afnita (2014) melakukan penelitian dengan judul "Pengaruh Budaya Organisasi Dan Kompensasi Terhadap Kinerja Karyawan Di BPJS Ketenagakerjaan Kantor Pusat". Hasilnya menunjukkan bahwa budaya organisasi berpengaruh signifikan terhadap kinerja karyawan, sedangkan kompensasi terbukti tidak berpengaruh signifikan terhadap kinerja karyawan.

Shaputra (2015) melakukan penelitian dengan judul "Pengaruh Kompetensi, Komitmen Dan Pengembangan Karir Terhadap Kinerja Karyawan PT. Bank Rakyat Indonesia (Persero) Kantor Wilayah Pekanbaru". Hasilnya menunjukkan variabel kompetensi, komitmen dan pengembangan karir berpengaruh signifikan terhadap kinerja karyawan.

\section{Hipotesis}

H1: Budaya organisasi, kompetensi dan motivasi berpengaruh signifikan secara simultan terhadap kinerja karyawan PDAM Tirta Binangun Kulonprogo.

$\mathrm{H} 2$ : Budaya organisasi berpengaruh signifikan terhadap kinerja karyawan PDAM Tirta Binangun Kulonprogo.

H3: Kompetensi berpengaruh signifikan terhadap kinerja karyawan PDAM Tirta Binangun Kulonprogo.

H4: Motivasi berpengaruh signifikan terhadap kinerja karyawan PDAM Tirta Binangun Kulonprogo. 


\section{METODE PENELITIAN}

\section{Populasi dan Sampel}

Populasi yaitu wilayah generalisasi yang terdiri dari obyek atau subyek yang mempunyai kualitas dan karakteristik tertentu yang ditetapkan oleh peneliti untuk dipelajari dan kemudian ditarik kesimpulannya (Sugiyono, 2018). Dalam penelitian ini yang dijadikan populasi adalah seluruh karyawan PDAM Tirta Binangun Kulonprogo dengan jumlah populasi sebanyak 120 karyawan. Sumber data peneliti didapatkan melalui informasi langsung dari kepala Direktur PDAM yang diperoleh pada bulan Oktober 2018.

Sampel adalah bagian dari jumlah dan karakteristik yang dimiliki oleh populasi tersebut (Sugiyono, 2018). Sampel yang diambil dalam penelitian ini berjumlah 60 karyawan yang sudah ditetapkan oleh kebijakan perusahaan, karena dalam PDAM Tirta Binangun Kulonprogo yang dapat dilakukan penelitian hanya di bagian pusat, seperti bagian keuangan dan pembukuan, bagian hubungan langganan, bagian umum dan bagian teknik.

\section{Definisi Operasional}

1. Variabel Independen

a. Budaya Organisasi

Indikator yang digunakan dalam menilai pengaruh budaya organisasi terhadap kinerja karyawan di antaranya: 1) inovasi dan pengambilan resiko, 2) perhatian terhadap detail, 3) orientasi pada hasil, 4) orientasi pada individu, 5) orientasi pada tim, 6) keagresifan dan 7) kestabilan.

b. Kompetensi

Indikator yang digunakan dalam menilai pengaruh kompetensi terhadap kinerja karyawan di antaranya: 1) motif, 2) sifat, 3) konsep diri, 4) pengetahuan dan 5) keterampilan. c. Motivasi

Indikator yang digunakan dalam menilai pengaruh motivasi terhadap kinerja karyawan di antaranya: 1) kebutuhan fisik, 2) kebutuhan rasa aman, 3) kebutuhan sosial, 4) kebutuhan penghargaan dan 5) kebutuhan aktualisasi diri.

\section{Variabel Dependen}

Variabel dependen yang digukana dalam penelitian ini adalah kinerja karyawan. Indikator yang digunakan dalam menilai kinerja karyawan di antaranya: 1) efektifitas dan efisien, 2) orientasi tanggungjawab, 3) disiplin dan 4) inisiatif.

\section{Uji Instrumen}

\section{Uji Validitas}

Uji validitas merupakan derajat ketepatan antara data yang terjadi pada obyek penelitian dengan data yang dapat dilaporkan oleh peneliti. Dengan demikian data yang valid adalah "yang tidak berbeda" antara data yang dilaporkan oleh peneliti dengan data yang sesungguhnya terjadi pada obyek penelitian (Sugiyono, 2018). Untuk melakukan uji validitas ini menggunakan program SPSS dengan menggunakan alat uji product moment untuk mengetahui kuesioner yang dibagikan ke responden valid atau tidak. Kriteria valid apabila $r$ hitung $>\mathrm{r}$ tabel berdasarkan uji signifikan sebesar 0,05 .

\section{Uji Reliabilitas}

Uji reliabilitas berkenaan dengan stabilitas data derajat konsistensi dan stabilitas data atau temuan. Dalam pandangan kuantitatif, suatu data dinyatakan reliabel apabila dua atau lebih peneliti dalam obyek yang sama, atau peneliti sama dalam waktu berbeda menghasilkan data yang sama, atau sekelompok data bila dipecah menjadi dua menunjukan data yang tidak 
berbeda (Staiback, 1988) dalam Sugiyono (2018). Uji reliabilitas ini digunakan untuk mengetahui apakah data hasil kuesioner dapat dipercaya atau tidak. Dan untuk melakukan uji reliabilitas ini menggunakan rumus Cronbach Alpha, jika nilai Cronbach Alpha di atas 0,60 maka dinyatakan reliabel.

\section{Teknik Analisis Data}

1. Analisis Regresi Berganda

Untuk mengetahui seberapa jauh pengaruh variabel independen terhadap variabel dependen, ditunjukkan dengan model regresi berganda sebagai berikut: $\mathrm{Y}=\mathrm{a}+\mathrm{b} 1 \mathrm{X} 1+\mathrm{b} 2 \mathrm{X} 2+\mathrm{b} 3 \mathrm{X} 3$

Keterangan:

Y=variabel dependen (kinerja karyawan). $\mathrm{a}=$ nilai konstanta.

b1, b2, b3 = koefisien variabel independen

$\mathrm{X} 1=$ variabel independen tentang (budaya organisasi).

$\mathrm{X} 2$ = variabel independen tentang (kompetensi).

X3 = variabel independen (motivasi).

\section{Uji Hipotesis}

\section{Uji Parsial (Uji T)}

Uji $\mathrm{T}$ digunakan untuk melihat pengaruh variabel indenpenden secara individual atau sendiri-sendiri terhadap variabel dependen. Kriteria penerimaan dan penolakan hipotesis sebagai berikut:

Jika nilai signifikan $<0,05$, maka Ho ditolak dan Ha diterima

Jika nilai signifikan >0,05, maka Ho diterima dan Ha ditolak

\section{Uji Simultan (Uji F)}

Uji $F$ digunakan untuk melihat pengaruh variabel independen secara keseluruhan terhadap variabel dependen. Kriteria penerimaan dan penolakan hipotesis sebagai berikut:
Jika nilai signifikan $<0,05$, maka Ho ditolak dan Ha diterima

Jika nilai signifikan >0,05, maka Ho diterima dan Ha ditolak

\section{Uji Koefisien Determinasi}

Nilai koefisien determinasi (R2) adalah pengkuadratan dari korelasi berkisar pada angka nol dan satu, dengan catatan semakin kecil angka koefisien, maka semakin lemah hubungan kedua variabel. (Adhila, 2014).

\section{HASIL PENELITIAN DAN PEMBAHASAN}

\section{Hasil Analisis Responden}

Karakteristik Berdasarkan Divisi/Bagian

\begin{tabular}{|l|l|l|}
\hline Divisi/Bagian & Frekuensi & Persentase (\%) \\
\hline kepala bagian & 8 & $13,33 \%$ \\
\hline staf & 6 & $10 \%$ \\
\hline inventaris & 1 & $1,67 \%$ \\
\hline \hline Logistik & 14 & $23,33 \%$ \\
\hline Operator & 3 & $5 \%$ \\
\hline Distribusi & 15 & $25 \%$ \\
\hline Administrasi & 10 & $16,66 \%$ \\
\hline Penanggung jawab & 1 & $1,67 \%$ \\
\hline analisis unit & 1 & $1,67 \%$ \\
\hline Penjaga & 1 & $1,67 \%$ \\
\hline Jumlah & 60 & $100 \%$ \\
\hline
\end{tabular}

Dari tabel di atas dapat dilihat bahwa responden terbanyak berada di divisi/bagian distribusi yaitu sebanyak 15 orang (25\%), kepala bagian sebanyak 8 orang $(13,33 \%)$, responden staf sebanyak 6 orang (10\%), inventaris 1 orang $(1,67 \%)$, operator sebanyak 14 orang $(23,33 \%)$, logistik 3 orang $(5 \%)$, administrasi 10 orang $(16,66 \%)$, penanggung jawab 1 orang $(1,67 \%)$, analisis unit 1 orang $(1,67 \%)$, dan Penjaga 1 orang $(1,67 \%)$. 
Karakteristik Berdasarkan Usia

\begin{tabular}{|l|l|l|}
\hline Usia & Frekuensi & Persentase (\%) \\
\hline$<30$ tahun & 31 & $51,67 \%$ \\
\hline $31-40$ tahun & 18 & $30 \%$ \\
\hline $41-50$ tahun & 11 & $18,33 \%$ \\
\hline Jumlah & $\mathbf{6 0}$ & $\mathbf{1 0 0} \%$ \\
\hline
\end{tabular}

Dari tabel di atas dapat dilihat bahwa responden terbanyak berada di usia $<30$ tahun dengan jumlah responden sebanyak 31 orang $(51,67 \%)$, responden pada usia $31-40$ tahun sebanyak 18 orang (30\%), responden pada usia 41-50 tahun sebanyak 11 orang $(18,33 \%)$.

Karakteristik Berdasarkan Jenis Kelamin

\begin{tabular}{|l|l|l|}
\hline Jenis Kelamin & Frekuensi & Persentase (\%) \\
\hline Laki - laki & 48 & $80 \%$ \\
\hline Perempuan & 12 & $20 \%$ \\
\hline Jumlah & $\mathbf{6 0}$ & $\mathbf{1 0 0} \%$ \\
\hline
\end{tabular}

Dari tabel di atas dapat dilihat bahwa responden di dominasi oleh responden laki-laki yaitu sebanyak 48 orang $(80 \%)$ dan responden perempuan sebanyak 12 orang (20\%).

Karakteristik Berdasarkan Pendidikan Terakhir

\begin{tabular}{|c|c|c|}
\hline $\begin{array}{c}\text { Pendidikan } \\
\text { Terakhir }\end{array}$ & Frekuensi & Persentase (\%) \\
\hline S2 & 1 & $1,67 \%$ \\
\hline S1 & 8 & $13,33 \%$ \\
\hline DIPLOMA & 2 & $3,33 \%$ \\
\hline SLTA & 49 & $81,67 \%$ \\
\hline Jumlah & $\mathbf{6 0}$ & $\mathbf{1 0 0} \%$ \\
\hline
\end{tabular}

Dari tabel di atas dapat dilihat bahwa responden terbanyak berada di jenjang SLTA yaitu sebanyak 49 orang $(81,67 \%)$, responden pada jenjang $\mathrm{S} 1$ sebanyak 8 orang $(13,33 \%)$, responden pada jenjang DIPLOMA sebanyak 2 orang $(3,33 \%)$ dan responden pada jenjang S2 sebanyak 1 orang $(1,67 \%)$.
Karakteristik Berdasarkan Masa Kerja

\begin{tabular}{|l|l|l|}
\hline Masa Kerja & Frekuensi & Persentase \\
\hline$<5$ Tahun & 23 & $38,33 \%$ \\
\hline $5-10$ Tahun & 16 & $26,67 \%$ \\
\hline$>10$ Tahun & 21 & $35 \%$ \\
\hline Jumlah & $\mathbf{6 0}$ & $\mathbf{1 0 0} \%$ \\
\hline
\end{tabular}

Dari tabel di atas dapat dilihat bahwa responden terbanyak berada pada masa kerja $<5$ tahun yaitu sebanyak 23 orang $(38,33 \%)$, masa kerja 5-10 tahun sebanyak 16 orang $(26,67 \%)$, masa kerja $>10$ tahun sebanyak 21 orang $(35 \%)$.

\section{Hasil Penelitian}

1. Hasil Uji Validitas

a. Variabel Budaya Organisasi

Tahap 1

Uji Validitas Variabel Budaya Oganisasi Tahap I

\begin{tabular}{|l|l|l|l|l|l|}
\hline Variabel & \multicolumn{1}{|c|}{ Indikator } & Item & $\mathbf{R}$ hitung & $\mathbf{R}$ tabel & keterangan \\
\hline Budaya & Inovasi dan & 1.1 & 0,548 & 0,374 & Valid \\
$\begin{array}{l}\text { Organisa } \\
\text { si } \\
\text { (X1) }\end{array}$ & mengambil & 1.2 & 0,299 & 0,374 & Tidak Valid \\
& resiko & & & & \\
\cline { 2 - 6 } & Memperhatikan & 2.1 & 0,525 & 0,374 & Valid \\
& detail & 2.2 & 0,592 & 0,374 & Valid \\
\cline { 2 - 6 } & Orientasi pada & 3.1 & 0,651 & 0,374 & Valid \\
& hasil & 3.2 & 0,591 & 0,374 & Valid \\
\cline { 2 - 6 } & Orientasi pada & 4.1 & 0,533 & 0,374 & Valid \\
& orang & 4.2 & 0,474 & 0,374 & Valid \\
\cline { 2 - 6 } & Orientasi pada & 5.1 & 0,086 & 0,374 & Tidak Valid \\
& tim & 5.2 & 0,618 & 0,374 & Valid \\
\cline { 2 - 6 } & Keagresifan & 6.1 & 0,441 & 0,374 & Valid \\
& & 6.2 & 0,146 & 0,374 & Tidak Valid \\
\cline { 2 - 6 } & Stabilitas & 7.1 & 0,681 & 0,374 & Valid \\
& & 7.2 & 0,374 & 0,374 & Valid \\
\hline
\end{tabular}

Berdasarkan tabel di atas, dapat disimpulkan bahwa dari 14 item pertanyaan pada budaya organisasi terdapat 3 pertanyaan yang tidak valid. Teknik ini membandingkan nilai $r$ hitung dengan $r$ tabel, $r$ tabel dicari pada signifikansi 0,05 dengan uji 2 sisi dan jumlah data $(\mathrm{n})=30, \mathrm{df}=\mathrm{n}-2$ maka didapat $r$ tabel sebesar 0,374 (pada tabel r). 
Tahap 2

Uji Validitas Variabel Budaya Organisasi Tahap II

\begin{tabular}{|l|l|l|l|l|l|}
\hline Variabel & \multicolumn{1}{|c|}{ Indikator } & Item & $\mathbf{R}$ hitung & $\mathbf{R}$ tabel & Keterangan \\
\hline $\begin{array}{l}\text { Budaya } \\
\text { Oganisasi }\end{array}$ & $\begin{array}{l}\text { Inovasi dan } \\
\text { mengambil }\end{array}$ & 1.1 & 0,532 & 0,374 & Valid \\
& resiko & - & - & - \\
\cline { 2 - 6 } & Memperhatikan & 2.1 & 0,584 & 0,374 & Valid \\
& detail & 2.2 & 0,672 & 0,374 & Valid \\
\cline { 2 - 6 } & Orientasi pada & 3.1 & 0,706 & 0,374 & Valid \\
& hasil & 3.2 & 0,642 & 0,374 & Valid \\
\cline { 2 - 6 } & Orientasi pada & 4.1 & 0,514 & 0,374 & Valid \\
& orang & 4.2 & 0,438 & 0,374 & Valid \\
\cline { 2 - 6 } & Orientasi Pada & 5.1 & - & - & - \\
& Tim & 5.2 & 0,692 & 0,374 & Valid \\
\cline { 2 - 6 } & Keagresifan & 6.1 & 0,399 & 0,374 & Valid \\
\cline { 2 - 6 } & 6.2 & - & - & - \\
\cline { 2 - 6 } & Stabilitas & 7.1 & 0,646 & 0,374 & Valid \\
& 7.2 & 0,339 & 0,374 & Tidak Valid \\
\hline \multirow{2}{*}{} & & \multicolumn{3}{|l}{} \\
\hline
\end{tabular}

Berdasarkan tabel di atas, dapat disimpulkan bahwa tahap II mengambil 11 item pertanyaan $\mathrm{BO} 1, \mathrm{BO} 3, \mathrm{BO} 4, \mathrm{BO} 5, \mathrm{BO} 6, \mathrm{BO} 7$, BO8, BO10, BO11, BO13, BO14 tetapi tedapat satu item pertanyaan yang tidak valid. Teknik ini membandingkan nilai $r$ hitung dengan $r$ tabel, $r$ tabel dicari pada signifikansi 0,05 dengan uji 2 sisi dan jumlah data $(\mathrm{n})=30$, df $=\mathrm{n}-2$ maka didapat $r$ tabel sebesar 0,374 (pada tabel r).

\section{Tahap 3}

Uji Validitas Variabel Budaya Oganisasi Tahap III

\begin{tabular}{|c|c|c|c|c|c|}
\hline Variabel & Indikator & Item & R hitung & $r$ tabel & Keterangan \\
\hline \multirow[t]{7}{*}{$\begin{array}{l}\text { Budaya } \\
\text { Oganisasi }\end{array}$} & $\begin{array}{l}\text { Inovasi dan } \\
\text { mengambil } \\
\text { resiko }\end{array}$ & $\begin{array}{l}1.1 \\
1.2\end{array}$ & $\begin{array}{l}0,533 \\
-\end{array}$ & 0,374 & Valid \\
\hline & $\begin{array}{l}\text { Memperhatikan } \\
\text { detail }\end{array}$ & $\begin{array}{l}2.1 \\
2.2\end{array}$ & $\begin{array}{l}0,594 \\
0,688\end{array}$ & $\begin{array}{l}0,374 \\
0,374\end{array}$ & $\begin{array}{l}\text { Valid } \\
\text { Valid }\end{array}$ \\
\hline & $\begin{array}{ll}\begin{array}{l}\text { Orientasi pada } \\
\text { hasil }\end{array} \\
\end{array}$ & $\begin{array}{l}3.1 \\
3.2 \\
\end{array}$ & $\begin{array}{l}0,719 \\
0,638 \\
\end{array}$ & $\begin{array}{l}0,374 \\
0,374\end{array}$ & $\begin{array}{l}\text { Valid } \\
\text { Valid } \\
\end{array}$ \\
\hline & $\begin{array}{l}\begin{array}{l}\text { Orientasi pada } \\
\text { orang }\end{array} \\
\end{array}$ & $\begin{array}{l}4.1 \\
4.2 \\
\end{array}$ & $\begin{array}{l}0,534 \\
0,464\end{array}$ & $\begin{array}{l}0,374 \\
0,374\end{array}$ & $\begin{array}{l}\text { Valid } \\
\text { Valid }\end{array}$ \\
\hline & $\begin{array}{ll}\text { Orientasi Pada } \\
\text { Tim }\end{array}$ & $\begin{array}{l}5.1 \\
5.2\end{array}$ & $\overline{0}, 718$ & 0,374 & Valid \\
\hline & Keagresifan & $\begin{array}{l}6.1 \\
6.2 \\
\end{array}$ & $\begin{array}{l}0,385 \\
- \\
\end{array}$ & $\begin{array}{l}0,374 \\
-\end{array}$ & Valid \\
\hline & Stabilitas & $\begin{array}{l}7.1 \\
7.2\end{array}$ & $\begin{array}{l}0,595 \\
-\end{array}$ & $\begin{array}{l}0,374 \\
-\end{array}$ & Valid \\
\hline
\end{tabular}

Berdasarkan tabel di atas, dapat disimpulkan bahwa tahap III dari 10 item pertanyaan $\mathrm{BO} 1, \mathrm{BO} 3$, $\mathrm{BO} 4, \mathrm{BO} 5, \mathrm{BO} 6, \mathrm{BO} 7, \mathrm{BO} 8, \mathrm{BO} 10$, BO11, BO13 dan menunjukan hasil yang valid. Teknik ini membandingkan nilai $r$ hitung dengan $r$ tabel, $r$ tabel dicari pada signifikansi 0,05 dengan uji 2 sisi dan jumlah data $(\mathrm{n})=30$, df $=\mathrm{n}-2$ maka didapat $r$ tabel sebesar 0,374 (pada tabel r). b. Variabel Kompetensi

Uji Validitas Variabel Kompetensi

\begin{tabular}{|l|l|l|l|l|l|}
\hline Variabel & Indikator & Item & $\mathbf{R}$ hitung & $\mathbf{R}$ tabel & Keterangan \\
\hline \multirow{3}{*}{$\begin{array}{l}\text { Kompete } \\
\text { nsi }\end{array}$} & Motif & 1.1 & 0,468 & 0,374 & Valid \\
& & 1.2 & 0,459 & 0,374 & Valid \\
\cline { 2 - 6 } & \multirow{4}{*}{ Sifat } & 2.1 & 0,625 & 0,374 & Valid \\
& & 2.2 & 0,778 & 0,374 & Valid \\
\cline { 2 - 6 } & Konsep Diri & 3.1 & 0,509 & 0,374 & Valid \\
& & 3.2 & 0,716 & 0,374 & Valid \\
\cline { 2 - 6 } & Pengetahuan & 4.1 & 0,508 & 0,374 & Valid \\
& & 4.2 & 0,475 & 0,374 & Valid \\
\cline { 2 - 6 } & keterampilan & 5.1 & 0,607 & 0,374 & Valid \\
& 5.2 & 0,656 & 0,374 & Valid \\
\hline
\end{tabular}

Berdasarkan tabel di atas, dapat disimpulkan bahwa dari 10 item pertanyaan pada kompetensi menunjukan semua item pertanyaan valid. Teknik ini membandingkan nilai $r$ hitung dengan $r$ tabel, $r$ tabel dicari pada signifikansi 0,05 dengan uji 2 sisi dan jumlah data $(n)=30$, df $=\mathrm{n}-2$ maka didapat $\mathrm{r}$ tabel sebesar 0,374 (pada tabel r).

c. Variabel Motivasi

Tahap 1

Uji Validitas Variabel Motivasi

\begin{tabular}{|l|l|l|l|l|l|}
\hline Variabel & Indikator & Item & $\begin{array}{c}\mathbf{R} \\
\text { hitung }\end{array}$ & $\begin{array}{c}\mathbf{R} \\
\text { tabel }\end{array}$ & Keterangan \\
\hline Motivasi & Kebutuhan & 1.1 & 0,497 & 0,374 & Valid \\
& Fisiologis & 1.2 & 0,609 & 0,374 & Valid \\
\cline { 2 - 6 } & Kebutuhan & 2.1 & 0,457 & 0,374 & Valid \\
& Keamanan & 2.2 & 0,046 & 0,374 & Tidak Valid \\
\cline { 2 - 6 } & Kebutuhan & 3.1 & 0,809 & 0,374 & Valid \\
& sosial & 3.2 & 0,546 & 0,374 & Valid \\
\cline { 2 - 6 } & Kebutuhan & 4.1 & 0,731 & 0,374 & Valid \\
& Penghargaan & 4.2 & 0,656 & 0,374 & Valid \\
\cline { 2 - 6 } & Kebutuhan & 5.1 & 0,546 & 0,374 & Valid \\
& Aktualisasi Diri & 5.2 & 0,458 & 0,374 & Valid \\
\hline
\end{tabular}

Berdasarkan tabel di atas, dapat disimpulkan bahwa dari 10 item pertanyaan pada motivasi terdapat satu item pertanyaan tidak valid. Teknik ini membandingkan nilai $r$ hitung dengan $r$ tabel, $r$ tabel dicari pada signifikansi 0,05 dengan uji 2 sisi dan jumlah data $(n)=30$, df $=\mathrm{n}-2$ maka didapat $\mathrm{r}$ tabel sebesar 0,374 (pada tabel r).

Tahap 2

Tabel Validitas Variabel Motivasi Tahap II

\begin{tabular}{|c|l|l|l|l|l|}
\hline Variabel & Indikator & Item & R hitung & R tabel & Keterangan \\
\hline Motivasi & Kebutuhan & 1.1 & 0,536 & 0,374 & Valid \\
& Fisiologis & 1.2 & 0,634 & 0,374 & Valid \\
\cline { 2 - 6 } & Kebutuhan & 2.1 & 0,405 & 0,374 & Valid \\
& Keamanan & 2.2 & & & - \\
\cline { 2 - 6 } & Kebutuhan & 3.1 & 0,841 & 0,374 & Valid \\
& sosial & 3.2 & 0,514 & 0,374 & Valid \\
\cline { 2 - 6 } & Kebutuhan & 4.1 & 0,759 & 0,374 & Valid \\
& Penghargaa & 4.2 & 0,685 & 0,374 & Valid \\
& n & & & & \\
\cline { 2 - 6 } & Kebutuhan & 5.1 & 0,565 & 0,374 & Valid \\
& Aktualisasi & 5.2 & 0,475 & 0,374 & Valid \\
& Diri & & & & \\
\hline
\end{tabular}


Berdasarkan tabel di atas, dapat disimpulkan bahwa dari 10 item pertanyaan pada motivasi tahap I terdapat 3 pertanyaan yang tidak valid, kemudian di uji coba dengan tahap II dengan mengambil 9 item petanyaan M1, M2, M3, M5, M6, M7, M8, M9, M10 dan menunjukan hasil yang valid. Teknik ini membandingkan nilai $r$ hitung dengan $r$ tabel, $r$ tabel dicari pada signifikansi 0,05 dengan uji 2 sisi dan jumlah data $(\mathrm{n})=30, \mathrm{df}=\mathrm{n}-2$ maka didapat $r$ tabel sebesar 0,374 (pada tabel r).

d. Variabel Kinerja Karyawan

Uji Validitas Variabel Kinerja Karyawan

\begin{tabular}{|l|l|l|l|l|l|}
\hline Variabel & Indikator & Item & $\mathbf{R}$ hitung & $\mathbf{R}$ tabel & keterangan \\
\hline Kinerja & Efektivitas \& & 1.1 & 0,474 & 0,374 & Valid \\
Karyawa & Efisiensi & 1.2 & 0,552 & 0,374 & Valid \\
\cline { 2 - 6 } & Orientasi & 2.1 & 0,687 & 0,374 & Valid \\
& Tanggung & 2.2 & 0,668 & 0,374 & Valid \\
& Jawab & & & & \\
\cline { 2 - 6 } & Disiplin & 3.1 & 0,604 & 0,374 & Valid \\
\cline { 2 - 6 } & & 3.2 & 0,694 & 0,374 & Valid \\
\cline { 2 - 6 } & Inisiatif & 4.1 & 0,619 & 0,374 & Valid \\
& & 4.2 & 0,473 & 0,374 & Valid \\
\hline
\end{tabular}

Berdasarkan tabel di atas, dapat disimpulkan bahwa dari 8 item pertanyaan pada kinerja karyawan menunjukan semua item pertanyaan valid. Teknik ini membandingkan nilai $r$ hitung dengan $r$ tabel, $r$ tabel dicari pada signifikansi 0,05 dengan uji 2 sisi dan jumlah data $(n)=30$, df $=n-2$ maka didapat $r$ tabel sebesar 0,374 (pada tabel r).

2. Hasil Uji Reliabilitas

\begin{tabular}{|l|l|l|}
\multicolumn{4}{|c|}{ Hasil Uji Reliabilitas } \\
\hline \multicolumn{1}{|c|}{ Variabel } & Croncbach Alpha & \multicolumn{1}{c|}{ Keterangan } \\
\hline Budaya Organisasi & 0,737 & Reliabel \\
\hline Kompetensi & 0,745 & Reliabel \\
\hline Motivasi & 0,749 & Reliabel \\
\hline Kinerja Karyawan & 0,744 & Reliabel \\
\hline
\end{tabular}

Berdasarkan tabel di atas menunjukkan bahwa setiap variabel yang digunakan dalam penelitian ini dinyatakan reliabel, hal ini dikarenakan nilai Cronbach's Alpha dari variabel kinerja karyawan 0,744 , budaya organisasi 0,737 , kompetensi 0,745 dan motivasi 0,749 lebih besar dari 0,60. Hal ini berarti bahwa semua jawaban responden sudah konsisten dalam menjawab setiap item pernyataan yang mengukur masing-masing variabel.

3. Hasil Uji Regresi Linier Berganda Hasil Uji Regresi Linier Berganda

\begin{tabular}{|l|l|l|}
\hline \multicolumn{1}{|c|}{ Variabel } & \multicolumn{1}{c|}{ B } & \multicolumn{1}{c|}{ Sign. } \\
\hline Constant & 1,423 & 0,015 \\
\hline Budaya Organisasi (X1) & 0,274 & 0,012 \\
\hline Kompetensi (X2) & 0,220 & 0,022 \\
\hline Motivasi (X3) & 0,188 & 0,016 \\
\hline
\end{tabular}

Berdasarkan hasil perhitungan di atas dengan menggunakan IBM SPSS Statistics 24 for Windows dapat diketahui persamaan regresi berganda linear sebagai berikut:

$\mathrm{Y}=1,423+0,274 \mathrm{X} 1+0,220 \mathrm{X} 2+$ $0,188 X 3$

Dari hasil persamaan regresi linier berganda di atas, dapat diinterpresikan sebagai berikut:

a. Nilai konstanta positif sebesar 1,423. Artinya apabila saat variabel budaya organisasi, kompetensi dan motivasi dalam keadaan tetap, maka kinerja karyawan akan meningkat.

b. Budaya organisasi mempunyai nilai koefisien regresi positif yaitu 0,274. Artinya yaitu setiap peningkatan satu satuan variabel budaya organisasi (X1) maka akan mampu meningkatkan kinerja karyawan sebesar 0,274.

c. Kompetensi mempunyai nilai koefisien regresi positif yaitu 0,220. Artinya yaitu setiap peningkatan satu satuan variabel Kompetensi (X2) maka akan mampu meningkatkan kinerja karyawan sebesar 0,220.

d. Motivasi mempunyai nilai koefisien regresi positif yaitu 0,188 . Artinya yaitu setiap peningkatan satu satuan variabel Motivasi (X3) maka akan mampu meningkatkan kinerja karyawan sebesar 0,188. 
4. Hasil Uji Parsial (Uji T)

Hasil Uji Signifikansi Parsial (Uji t)

\begin{tabular}{|l|c|c|l|}
\hline \multicolumn{1}{|c|}{ Variabel } & \multicolumn{1}{c|}{ T } & Sig. & Keterangan \\
\hline Budaya Organisasi (X1) & 2,612 & 0,012 & Signifikan \\
\hline Kompetensi (X2) & 2,360 & 0,022 & Signifikan \\
\hline Motivasi (X3) & 2,492 & 0,016 & Signifikan \\
\hline
\end{tabular}

a. Variabel Budaya Organisasi

Dilihat dari nilai sig hitung < alpha (0,05). Pada tabel di atas diperoleh nilai sig hitung sebesar 0,012 hal ini menunjukkan bahwa nilai sig hitung $0,012<0,05$, maka dapat disimpulkan bahwa hipotesis Ha1 diterima dan H01 ditolak, yang berarti bahwa terdapat pengaruh signifikan antara variabel budaya organisasi (X1) terhadap kinerja karyawan (Y) pada PDAM Tirta Binangun Kabupaten Kulonprogo.

b. Variabel Kompetensi

Dilihat dari nilai sig hitung < alpha (0,05). Pada tabel di atas diperoleh nilai sig hitung sebesar 0,022 hal ini menunjukkan bahwa nilai sig hitung $0,022<0,05$, maka dapat disimpulkan bahwa hipotesis Ha2 diterima dan $\mathrm{H} 02$ ditolak, yang berarti bahwa terdapat pengaruh signifikan antara variabel kompetensi (X2) terhadap kinerja karyawan (Y) PDAM Tirta Binangun Kulon Progo.

c. Variabel Motivasi

Dilihat dari nilai sign hitung < alpha (0,05). Pada tabel di atas diperoleh nilai sig hitung sebesar 0,016 hal ini menunjukkan bahwa nilai sig hitung $0,016<0,05$, maka dapat disimpulkan bahwa hipotesis Ha3diterima dan H03 ditolak, yang berarti bahwa terdapat pengaruh signifikan antara variabel motivasi (X3) terhadap kinerja karyawan (Y) PDAM Tirta Binangun Kulon Progo.
5. Hasil Uji Simultan (Uji F)

Hasil Uji Signifikansi Simultan (Uji F)

\begin{tabular}{|c|c|}
\hline F & Sig. \\
\hline 8,983 & 0,000 \\
\hline
\end{tabular}

Berdasarkan hasil uji simultan di atas, F hitung sebesar 8,983 diperoleh dengan taraf signifikansi 0,05 (sig. hitung $0,000<0,05$ ). Sehingga dapat disimpulkan bahwa budaya organisasi (X1), kompetensi (X2) dan motivasi (X3) secara simultan berpengaruh signifikan terhadap kinerja karyawan (Y) pada PDAM Tirta Binangun Kabupaten Kulonprogo.

\section{Hasil Uji Koefisien Determinasi}

\section{Hasil Perhitungan Koefisien Determinasi}

\begin{tabular}{|c|}
\hline R. Square \\
\hline 0,325 \\
\hline
\end{tabular}

Pada tabel di atas dapat dilihat bahwa nilai R2 sebesar 0,325. Dapat diartikan bahwa variabel independen yaitu variabel budaya organisasi (X1), kompetensi (X2) dan motivasi (X3) dapat menjelaskan variabel dependen yaitu variabel kinerja karyawan (Y) sebesar 32,5\%, sedangkan sisanya $(100 \%-32,5 \%=67,5 \%)$ dijelaskan oleh faktor lain seperti: lingkungan kerja, disiplin, stres kerja, kepemimpinan, kepuasan kerja, pelatihan, kompensasi, dan lain-lain.

\section{Pembahasan}

1. Pengaruh Budaya Organisasi, Kompetensi dan Motivasi terhadap Kinerja Karyawan pada PDAM Tirta Binangun Kabupaten Kulonprogo.

F hitung sebesar 8,983 diperoleh dengan taraf signifikansi 0,05 (Sig hitung $0,000<0,05)$. Sehingga dapat disimpulkan bahwa budaya organisasi (X1), kompetensi (X2) dan motivasi (X3), berpengaruh secara simultan memiliki pengaruh yang signifikan terhadap kinerja karyawan (Y) pada PDAM Tirta Binangun Kabupaten Kulonprogo. 
Budaya organisasi, kompetensi dan motivasi sama-sama memiliki pengaruh yang positif terhadap kinerja karyawan. Karena apabila budaya organisasi, kompetensi dan motivasi kurang baik maka kinerja karyawan yang dihasilkan juga akan kurang baik. Dan sebaliknya apabila budaya organisasi, kompetensi dan motivasi baik maka kinerja karyawan yang dihasilkan juga akan baik, karena hal ini mampu meningkatkan kinerja karyawan menjadi lebih optimal.

Dari penjelasan di atas dapat disimpulkan jika karyawan memiliki budaya organisasi, kompetensi dan motivasi yang baik maka akan lebih mudah dalam mencapai target atau tujuan suatu perusahaan. Penelitian ini juga didukung dengan penelitian yang dilakukan oleh Ainanur dan Tirtayasa (2018), yang menunjukkan bahwa terdapat pengaruh yang positif dan signifikan antara variabel budaya organisasi, kompetensi dan motivasi terhadap kinerja karyawaan.

2. Pengaruh Budaya Organisasi terhadap Kinerja Karyawan pada PDAM Tirta Binangun Kabupaten Kulonprogo.

Signifikansi yang diperoleh variabel budaya organisasi sebesar 0,012. Hal ini menunjukkan bahwa nilai sig $0,012<0,05$. Maka dapat disimpulkan bahwa hipotesis Ha1 diterima dan H01 ditolak, yang berarti bahwa terdapat pengaruh signifikan antara variabel budaya organisasi (X1) terhadap kinerja karyawan (Y) pada PDAM Tirta Binangun Kabupaten Kulonprogo.

Skor terendah pada variabel budaya organisasi ditunjukkan pada indikator memperhatikan detail, yaitu dengan jumlah skor sebesar 243. Hal ini menunjukkan bahwa ketepatan kerja di PDAM Tirta Binangun masih kurang, karena sebagian karyawan masih kurang tepat dalam menyelesaikan tugasnya.
Dari penjelasakan diatas dapat disimpulkan bahwa adanya budaya organisasi yang baik terhadap karyawan PDAM Tirta Binangun maka akan menghasilka kinerja karyawan yang baik, karena dengan adanya budaya organisasi yang sesuai akan membuat sebuah perusahaan berjalan dengan baik. Karena saat karyawan merasa nyaman maka karyawan akan menghasilkan kinerja yang lebih baik dan tepat. Dan sebaliknya, apabila budaya organisasi kurang tepat maka akan menghasilkan kinerja karyawan yang kurang baik pula. Penelitian ini juga didukung dengan penelitian yang dilakukan oleh Afnita (2014) yang mengatakan hasil penelitian ini menunjukkan bahwa budaya organisasi berpengaruh signifikan terhadap kinerja karyawan.

3. Pengaruh Kompetensi terhadap Kinerja Karyawan pada PDAM Tirta Binangun Kabupaten Kulonprogo.

Signifikansi yang diperoleh variabel kompetensi sebesar 0,022. Hal ini menunjukkan bahwa nilai sig $0,022<0,05$. Maka dapat disimpulkan bahwa hipotesis $\mathrm{Ha} 2$ diterima dan $\mathrm{H} 02$ ditolak, yang berarti bahwa terdapat pengaruh signifikan antara variabel kompetensi (X2) terhadap kinerja karyawan (Y) PDAM Tirta Binangun Kulon Progo.

Skor terendah pada variabel kompetensi ditunjukkan pada indikator sifat, yaitu dengan jumlah skor sebesar 224. Hal ini menunjukkan bahwa tingkat kekreatifan pada karyawan PDAM Tirta Binangun masih kurang, karena masih banyak karyawan yang belum bisa menunjukan kemampuannya untuk berinovasi dan menghasilkan potensi yang baik. Adaptasi yang baik terhadap rekan kerja maupun atasan akan dapat mewujudkan pencapaian tujuan suatu perusahaan dan meningkatkan kepercayaan diri setiap karyawan, karena ketika 
karyawan PDAM Tirta Binangun memiliki inovasi yang tinggi maka akan bekerja lebih baik lagi.

Dari penjelasakan diatas dapat disimpulkan bahwa adanya inovasi yang lebih baik terhadap karyawan PDAM Tirta Binangun maka akan menghasilkan kinerja karyawan yang baik, dan sebaliknya apabila tingkat inovasi pada karyawan PDAM Tirta Binangun rendah maka akan menghasilkan kinerja karyawan yang kurang baik. Penelitian ini juga didukung dengan penelitian yang dilakukan oleh Shaputra (2015) menunjukkan variabel kompetensi berpengaruh signifikan terhadap kinerja karyawan.

4. Pengaruh Motivasi terhadap Kinerja Karyawan pada PDAM Tirta Binangun Kabupaten Kulonprogo

Signifikansi yang diperoleh variabel motivasi sebesar 0,016 . Hal ini menunjukkan bahwa nilai sig 0,016 $<0,05$. Maka dapat disimpulkan bahwa hipotesis Ha3 diterima dan H03 ditolak, yang berarti bahwa terdapat pengaruh signifikan antara variabel motivasi $\left(\mathrm{X}_{3}\right)$ terhadap kinerja karyawan (Y) pada PDAM Tirta Binangun Kabupaten Kulonprogo.

Skor terendah pada variabel motivasi ditunjukkan pada indikator kebutuhan sosial, yaitu dengan jumlah skor sebesar 202. Hal ini menunjukkan bahwa tingkat motivasi pada karyawan PDAM Tirta Binangun masih kurang, karena masih banyak karyawan yang kurang mendapatkan dorongan dari atasan yang akan membuat kinerjanya lebih baik, hal seperti ini berpotensi membuat karyawan tidak bersemangat saat bekerja. Tingkat motivasi yang tinggi akan berpengaruh terhadap pencapaian tujuan suatu perusahaan, ketika karyawan PDAM Tirta Binangun memiliki motivasi yang tinggi akan membuat karyawan lebih bersemangat. Agar tujuan perusahaan dapat dicapai maka kinerja karyawan PDAM Tirta Binangun dapat ditingkatkan motivasinya yang lebih baik.

Dari penjelasan di atas dapat disimpulkan bahwa adanya motivasi yang baik terhadap karyawan PDAM Tirta Binangun maka akan menghasilkan kinerja karyawan yang baik, dan sebaliknya apabila tingkat motivasi pada karyawan PDAM Tirta Binangun rendah maka akan menghasilkan kinerja karyawan yang kurang baik. Penelitian ini juga didukung dengan penelitian yang dilakukan oleh Suwati (2013) yang mengatakan hasil penelitian ini menunjukkan bahwa motivasi berpengaruh signifikan terhadap kinerja karyawan.

\section{KESIMPULAN DAN SARAN}

\section{Kesimpulan}

1. Variabel budaya organisasi, kompetensi dan motivasi berpengaruh secara simultan berpengaruh signifikan terhadap kinerj karyawan PDAM Tirta Binangun Kabupaten Kulonprogo.

2. Variabel budaya organisasi berpengaruh signifikan terhadap kinerja karyawan PDAM Tirta Binangun Kabupaten Kulonprogo.

3. Variabel kompetensi berpengaruh signifikan terhadap kinerja karyawan PDAM Tirta Binangun Kabupaten Kulonprogo.

4. Variabel motivasi berpengaruh signifikan terhadap kinerja karyawan PDAM Tirta Binangun Kabupaten Kulonprogo.

\section{Saran}

1. Bagi PDAM Tirta Binangun Kabupaten Kulonprogo

PDAM Tirta Binangun

Kabupaten Kulonprogo harus mampu menunjukan ketepatan dalam bekerja, menunjukan kerjasama yang baik 
terhadap rekan kerja dan mendorong karyawan untuk berpotensi, sehingga dapat terus untuk mengembangkan dan mempertahankan kinerja karyawan yang sudah baik ini agar segala target dan tujuan perusahaan dapat dicapai secara maksimal.

2. Bagi Peneliti Selanjutnya

a. Peneliti selanjutnya dapat menambahkan variabel lainnya yang berhubungan dengan kinerja karyawan, sehingga dapat memberikan gambaran yang lebih luas mengenai faktor apa saja yang mempengaruhi kinerja karyawan selain budaya organisasi, kompetensi dan motivasi.

b. Hasil penelitian ini dapat menjadi referensi bagi penelitian selanjutnya untuk bidang yang sama.

\section{DAFTAR PUSTAKA}

Adhila, Fitroh, dkk. (2014). Petunjuk Praktikum Statistik 2. Yogyakarta.

Afnita, Mita, dkk. (2014). Pengaruh Budaya Organisasi Dan Kompensasi Terhadap Kinerja Karyawan Di Bpjs Ketenagakerjaan Kantor Pusat. Jurnal Analisis. Hal.172.

Fahmi, Irham. (2016). Pengantar Manajemen Sumber Daya Manusia Konsep Dan Kinerja. Jakarta: Mitra Wacana Media.

Kreitner, Robert Dan Angelo Kinicki. (2005). Perilaku Organisasi. Jakarta: Salemba Empat.

Robbins, Stephen P. Dan Timothy A. Judge. (2017). Perilaku Organisasi. Jakarta: Salemba Empat.

Shaputra, dkk. 2015. Pengaruh Kompetensi, Komitmen Dan Pengembangan Karir Terhadap Kinerja Karyawan PT. Bank Rakyat Indonesia (Persero) Kantor
Wilayah Pekanbaru. Jurnal Tepak Manajemen Bisnis.

Sinambela, Lijan Poltak. (2012). Kinerja Pegawai. Yogyakarta: Graha Ilmu.

Sugiyono. (2018). Metodologi Penelitian Kuantitatif, Kualitatif Dan $R \& D$. Bandung: Alfabeta.

Suwati, Yuli. (2013). Pengaruh Kompensasi Dan Motivasi Kerja Terhadap Kinerja Karyawan Pada PT. Tunas Hijau Samarinda. Jurnal Ilmu Administrasi Bisnis. Hal.49.

Wibowo. (2014). Manajemen Kinerja. Edisi Keempat. Jakarta: Rajawali Pers. 